\title{
The examination of signaling theory versus pecking order theory: Evidence from Tehran Stock Exchange
}

\author{
Mohammad Hassani $^{\mathrm{a}^{*}}$ and Elahe Mahdavi Sabet ${ }^{\mathrm{b}}$
}

${ }^{a}$ Head of Accounting Department, Management \& Social Science Faculty, Islamic Azad University-Tehran North Branch, Iran ${ }^{b}$ Master in Accounting, Islamic Azad University,Tehran North Branch, Iran

\section{H R O N I C L E \\ A B S T R A C T}

Article history:

Received June 25, 2012

Received in revised format

28 October 2012

Accepted 30 October 2012

Available online

November 22012

Keywords:

Cash flow

Leverage level

Signaling theory

Pecking order theory

\begin{abstract}
This study investigates the explanatory power of leverage and cash flows in future cash flow prediction in Tehran Stock Exchange by considering Signaling Theory and Pecking Order Theory. Based on theoretical foundations, the regression models of leverage and cash flow with a set of control variables was developed. Statistical samples consist of companies listed in Tehran Stock Exchange over the period 2005- 2011. The results show that there was a negative relationship between cash flow and leverage levels in contemporary time. This is consistent with pecking order behavior. While at intertemporer level, there was a positive relationship between current leverage and the firm's cash flows in the future. This is consistent with signaling theory.
\end{abstract}

\section{Introduction}

The economical organizations identify every factor affecting the organization development aiming at achieving their objectives. One of the factors with huge effect on organization success to achieve the goals is the cash in which the failure to set a plan could bring numerous problems for an organization. The knowledge about the available annual cash for an organization is not only very useful but also available cash prediction could culminate to appropriate planning for organization resources and usage in the future. In fact, a company will be more successful if it predicts its needs for sources from present time and pacing forward to fulfill the need, accordingly. In other words, the company growth needs financial resources in which decision making on how to use different financial resources given their limitation and determining the optimal capital structure constitute are some of the most important challenges for the mangers. Financial sources of every firm comprise internal and external sources. Internal sources include cash flow derived from operations in addition to funds from the sale of assets and external sources include borrowing from financial markets and issuing stocks. In each 
firm, accessible funds are used for paying dividends, recouping liabilities, investment in new fixed assets and increasing working capital. If the change in working capital is negative, the additional required sources will be met via external sources or sale of firm's assets and if the figure is positive, the excess will be employed for covering the debts, new investments or dividend increase (Rahimian, 2001).

\section{Literature Review}

Companies can acquire funding in two ways to implement profitable projects, which include financing via equity and financing via adopting financial leverage or creating liabilities.

\subsection{Theories related to selection between debt and equity}

\section{Traditional Theory}

According to traditional theory, optimal capital structure and capital costs are designed based on the capital structure. The optimal ratio of debt to equity with the least costs must be placed between debt and equity financing. Therefore, optimal capital structure is a point in which total firm costs is the minimum.

\section{Modigliani-Miller Theory}

In 1985, Modigliani-Miller described that under certain assumptions including existence of a full compatible market, absence of income taxes, bankruptcy costs, agency costs and existence of symmetric information among capital market stakeholders, changing of capital structure has no impact on company value. However, in 1963, upon integrating tax shield they had already described that debts creates tax shield for the company and companies should use more debt in order to increase company value (Ross et al., 2002).

\section{Signaling Theory}

In 1977, Ross for the first time, put forward the debt tool as signaling approach and described that this tool can be employed when asymmetric information between managers and outside investors. On the other hand, the managers have more information rather than outside investors about financial position and current and future company performance trying not to use debt when the company performance is poor due to high possibility for bankruptcy (Chen \& Strange, 2005). According to signaling theory, the relationship between cash flow and leverage level describing that managers use leverage as signaling tool is employed by investors in quality assessment of the company in terms of cash flow level. The high quality companies will use long term debt rather than other companies (Ross, 1977).

\section{Pecking Order Theory}

In continuation of signaling theory, Myers (1984) and Myers and Majluf (1984) put forward a more complex model describing that any funding requirement urges the company to change capital structure. Companies prioritize their sources of financing, first prefer internal financing, and then debt without risk or with negligible risk, risky debt and finally stocks that they prefer preferred stock to common stock (Chen \& Strange, 2005). According to Pecking Order Theory, in terms of relationship between cash flow and leverage level, Myers and Majluf (1984) stipulated that good quality companies create better internal cash flow. If dividends and investment remained constant, the long term debt would be a function of residual cash flow for a definite period of time. The company 
will issue long term debt when internal cash flow dose not fulfill the required funding. According to this Theory, there is a negative relationship between leverage and cash flow (Myers \& Majluf, 1984).

\section{Static Trade-off Theory}

The optimal capital structure underpins the static trade-off Theory. This structure is a combination of various funding sources balancing costs and profits of funding through using debts. In addition, it is assumed that there is an optimal or targeted financial leverage ratio that any deviation from this figure could be deemed as a bad news for the market. This optimal financial leverage could be detected via balancing profits and costs of extra debts (Chen \& Strange, 2005).

\section{Research Background}

Concerning cash flow forecasts, numerous studies have been conducted in Iran although no practical trial has been ever performed regarding combinational impact of leverage and cash flows over future cash flows. Jalali (2003) conducted a survey on Tehran Stock Exchange and concluded that financial leverage and degree of financial leverage changes poorly affect periodical cash flow but in positive way. In other words, an increase in financial leverage can boost company cash flow followed by cash flow derived from operations activities and financing but no association was found between financial leverage and cash flow derived from investment activities. Rezvani Raz and Haghighat (2005) carried out a study on relationship between free cash flows and debt rate by considering the investment opportunities and size in Tehran Stock Exchange listed companies. According to this study, there is a significant and positive association between free cash flow and debt rate in companies with low investment opportunities and in large corporations. In addition, they concluded that in Tehran stock exchange listed companies, the investors and creditors consider internal funding source and assessment criteria of debt recouping capability namely the free cash flow in their decision for investment and granting credits.

Harris and Raviv (1991) showed that, using high-level leverage could usually culminate to high cash flow creating by the company on the related time. On the other hand, the investors feel problems for assessment of investment decision adopted by the managers. The manager adopted decision for investment could be evaluated simply via pursuing the cash flow induced in the future. However, the investors can evaluate the financing related decisions adopted by the managers relying on the company leverage level.

Blazenko (1987), Poitevin (1989), Ravid and Sarig (1991) suggested that that higher leverage level will produce high cash flow level in the future implying a positive relation between leverage and cash flow. Shenoy and Koch (1996) studied the relationship between leverage (level of using debt) and cash flows in the companies employing signaling theory and pecking order theory and concluding that asymmetric information model was able to explain the relationship between the choice of corporate financing and cash flow. Pecking order theory and signaling theory are two models that seemingly have contradictory implications, in which the pecking order theory implies a negative relationship in contemporary period while the signaling theory implies a positive relationship in intertemporarty period.

In a research conducted by Wahyudi (2011) a simultaneous panel dynamic model was used to study leverage-cash flow relationships for public companies in Indonesia over the period 1997-2000. The results indicated a negative relationship between leverage level and cash flow in contemporary time. This is consistent with pecking order theory. While at intertemporer level, there was a positive relationship between current leverage and the firm's cash flows in the future and this is consistent with signaling theory. 


\section{Study Hypotheses}

Three hypotheses were studied in this research:

$\mathrm{H}_{1}$ : Leverage has important explanatory power to prediction of future cash flow.

$\mathrm{H}_{2}$ : Cash flows have important explanatory power to prediction of future cash flow.

$\mathrm{H}_{3}$ : Control variables have an important effect on this relation.

\subsection{Study statistical population and samples}

The statistical population in the present study is on Tehran Stock Exchange and sampling was conducted in eliminatory basis i.e. companies with following requirements were included in the statistical population and companies did not found qualified for the following requirements were eliminated from the study. The requirements were as follow:

1. The company financial information was available from March 21, 2005 to March 20, 2011.

2. The company has not experienced change in fiscal year during above period of time.

3. The company fiscal year terminated to March 20 of each year.

4. The company was admitted in Tehran Stock Exchange by March 20, 2005 and the company was not expelled from Stock exchange during the above period of time.

5. The company is not investment or Multidisciplinary industrial company (according to Stock exchange organization definition).

6. The company has been a profitable company during the above mentioned period of time.

The present study was conducted over the period 2005-2011 but given that study variables in benchmark year require two previous year data for data production purpose, four year data namely 2007 to 2011 was placed as the benchmark.

\subsection{Study Variables}

Free cash flow: free cash flow is equal to operational cash flow minus capital expenditure.

Free cash flow to firm $($ FCFF $)=($ Operational Cash Flow - Capital Expenditure $) /$ Total Assets

Leverage level: Leverage ratio used in this study is ratio of total book value of long term debts to total long term debts and equity.

Leverage $($ LEV $)=$ Total Book Value of Long-term Debt / Total Long-term Debt and Equity

Investment level: Ratio of changes in fixed assets to total assets.

Investment $(\mathrm{INV})=\Delta$ Fixed Asset $/$ Total Asset

Dividend: Ratio of paid dividends to total assets.

Dividend $(\mathrm{DIV})=$ Dividend Paid $/$ Total Asset

Tax Shield: Ratio of Depreciation to total assets. 
Tax Shield $(\mathrm{TAX})=$ Depreciation $/$ Total Asset

Tangible Assets: Ratio of fixed assets to total assets.

Tangible asset $($ TGAST $)=$ Total Fixed Asset $/$ Total Asset

Size: Logarithm of total assets.

$\mathrm{SIZE}=\mathrm{Ln}($ Total Asset $)$

Growth Opportunities: Ratio of equity market value (stock numbers multiplied by market value per share on the last day of transaction in study year) to equity book value.

Growth $=\mathrm{MV}_{\text {Equity }} / \mathrm{BV}_{\text {Equity }}$

Profitability: Return on Assets (ROA) is employed as criteria for profitability calculated as ratio of Net Operating Profit After Tax to Total assets.

Rerun on Assets $($ ROA $)=$ NOPAT $/$ Total Asset

\subsection{Analysis methods}

The relationships among variables were studied using analysis of acquired data. Analysis was performed in 2 parts: descriptive statistics and inferential statistics.

\section{Findings}

As described earlier, the data related to samples were collected over the period 2005- 2011 for 126 companies relying on data collection tools.

\subsection{Study Variables Description}

In descriptive part of this study, central tendency, distribution and tables were employed. The central tendency features were studied relying on mean and distribution features on standard deviation, variance and skewness and Kurtosis. Table 1 shows descriptive statistics:

\section{Table 1}

Indices of study variables descriptive statistics

\begin{tabular}{lllllllc}
\hline \multicolumn{1}{c}{ Variables } & Mean & $\begin{array}{c}\text { Standard } \\
\text { Deviation }\end{array}$ & Variance & Skewness & Kurtosis & \multicolumn{2}{c}{ Coefficient } \\
Skewness & Kurtosis \\
\hline FCFF & 0.189 & 0.149 & 0.022 & 0.456 & 5.181 & 5.124 & 29.107 \\
FCFF(-1) & 0.188 & 0.147 & 0.022 & 0.341 & 5.104 & 3.515 & 26.309 \\
FCFF(-2) & 0.187 & 0.151 & 0.023 & 0.249 & 5.158 & 2.284 & 23.769 \\
LEV & 0.164 & 0.139 & 0.019 & 1.553 & 2.301 & 17.449 & 12.927 \\
LEV(-1) & 0.166 & 0.142 & 0.020 & 1.558 & 2.302 & 16.062 & 11.866 \\
LEV(-2) & 0.170 & 0.144 & 0.021 & 1.554 & 2.337 & 14.257 & 10.769 \\
INV & 0.025 & 0.088 & 0.008 & 3.095 & 26.667 & 34.775 & 149.815 \\
DIV & 0.112 & 0.099 & 0.010 & 1.631 & 3.391 & 18.326 & 19.050 \\
TAX & 0.025 & 0.018 & 0.000 & 1.112 & 0.971 & 12.494 & 5.455 \\
TGAST & 0.263 & 0.171 & 0.029 & 0.824 & 0.426 & 9.258 & 2.393 \\
SIZE & 13.239 & 1.292 & 1.669 & 0.918 & 1.352 & 10.315 & 7.596 \\
GROWTH & 2.191 & 2.334 & 5.450 & 7.157 & 86.468 & 80.416 & 485.775 \\
ROA & 0.149 & 0.093 & 0.009 & 1.291 & 2.002 & 14.506 & 11.247 \\
\hline
\end{tabular}




\subsection{Analysis of study data and variables nature}

The information was collected from sample population comprises of Tehran stock exchange admitted companies and the study sought to test the impact and control of a set of explanatory variables including independent variables over dependent variable. The regression analysis is the most appropriate test for this purpose. The study data collected in cross-sectional and time series manner requiring regression analysis implication based on panel data. This study model is fitted for data of randomized-cross sectional impacts. Using this method demands assumptions discussed later on.

1. Study variables distribution test: One of the assumptions to use parametric tests is the normality of variable distribution. If the sample volume is large, failure to fulfill this assumption is acceptable. In the present study, Kolmogorov-Smirnov test and Jarque-Bera test were employed to study variables distribution. The smallness of calculated significant level suggested non-normality of the distribution. The acquired results by these two test methods indicated non-normality of study variables distribution. The results are shown in Table 2:

\section{Table 2}

Study variables test results

\begin{tabular}{llclc}
\hline \multirow{2}{*}{ Variables } & \multicolumn{2}{c}{ Kolmogorov-Smirnov test } & \multicolumn{2}{c}{ Jarque-Bera test } \\
& Statistic & P-Value & Statistic & P-Value \\
\hline FCFF & 2.311 & 0.000 & 906.181 & 0.000 \\
FCFF(-1) & 2.135 & 0.000 & 725.236 & 0.000 \\
FCFF(-2) & 1.984 & 0.001 & 550.357 & 0.000 \\
LEV & 3.649 & 0.000 & 350.220 & 0.000 \\
LEV(-1) & 3.735 & 0.000 & 329.697 & 0.000 \\
LEV(-2) & 3.619 & 0.000 & 312.799 & 0.000 \\
INV & 4.461 & 0.000 & 26719.26 & 0.000 \\
DIV & 2.855 & 0.000 & 606.610 & 0.000 \\
TAX & 2.447 & 0.000 & 95.610 & 0.000 \\
TGAST & 1.897 & 0.001 & 108.075 & 0.000 \\
SIZE & 1.661 & 0.008 & 105.042 & 0.000 \\
GROWTH & 2.755 & 0.000 & 500.820 & 0.000 \\
ROA & 2.242 & 0.000 & 270.122 & 0.000 \\
\hline
\end{tabular}

2. Non-collinearity among independent variables: Collinearity means existence of linear relation among explanatory or independent variables. Studying correlation relation among independent variables is one of the methods for identifying collinearity and non-collinearity relation. If the correlation among independent variables is not strong, there will be no collinearity problem. The Pearson correlation coefficient was employed to study collinearity among independent variables. As one seen in the tables the intensity of relation between dividend and profitability was strong and simultaneous use of them min the model can create collinearity problem. The test results are described in Table 3.

Table 3

Study independent variables correlation tests results

\begin{tabular}{|c|c|c|c|c|c|c|c|c|c|c|c|c|}
\hline VARIABLE & $\mathrm{FCFF}(-1)$ & $\mathrm{FCFF}(-2)$ & LEV & $\operatorname{LEV}(-1)$ & $\operatorname{LEV}(-2)$ & INV & DIV & TAX & TGAST & SIZE & GROW & ROA \\
\hline FCFF(-1) & 1 & & & & & & & & & & & \\
\hline $\mathrm{FCFF}(-2)$ & 0158 & 1 & & & & & & & & & & \\
\hline LEV & -0.206 & -0.205 & 1 & & & & & & & & & \\
\hline $\operatorname{LEV}(-2)$ & -0.141 & -0.223 & 0.640 & 0.783 & 1 & & & & & & & \\
\hline INV & 0.048 & 0.028 & 0.204 & 0.090 & 0.092 & 1 & & & & & & \\
\hline DIV & 0.447 & 0.398 & -0.281 & -0.228 & -0.129 & 0.035 & 1 & & & & & \\
\hline TAX & 0.088 & -0.015 & 0.103 & 0.207 & 0.241 & -0.185 & 0.020 & 1 & & & & \\
\hline TGAST & -0.040 & -0.088 & 0.391 & 0.401 & 0.400 & 0.404 & -0.012 & 0.563 & 1 & & & \\
\hline SIZE & -0.029 & -0.031 & 0.168 & 0.168 & 0.150 & 0.073 & 0.028 & -0.151 & 0.057 & 1 & & \\
\hline GROW & 0.248 & 0.315 & -0.096 & -0.087 & -0.034 & 0.159 & 0.489 & -0.158 & -0.004 & 0.020 & 1 & \\
\hline ROA & 0.432 & 0.347 & -0.294 & -0.227 & -0.122 & 0.040 & 0.874 & 0.020 & -0.004 & 0.011 & 0.525 & 1 \\
\hline
\end{tabular}




\subsection{Results of study hypothesis test}

Model 1 has studied the explanatory power of leverage in future cash flow prediction and Table 4 shows details of regression estimation. The interpretation of regression analysis using table 4 is as follows:

According to Fischer's results in model 1, the statistic $\mathrm{F}$ is larger than critical figure and their significance area is less than 0.05 . Therefore, there is a linear relation between independent and dependent variables. In addition, Durbin Watson statistic in model 1 is between 1.70 and 2.30 suggesting lack of autocorrelation in fitted model. $\mathrm{R}^{2}$ coefficient shows that about $53 \%$ of cash flow changes are determined by 9 explanatory variables. Statistic t-student for Tax shield, size, 2 previous times leverage was smaller than critical figure and calculated significance area was higher than 0.05 suggesting the non significant impact of these three variables. Other explanatory variables of the model were found significant. Therefore, one can assume that impact of current period leverage and investment level over cash flows of stock exchange companies is significant and inversed. Effect of previous period leverage, dividend, ratio of fixed assets and growth opportunities over cash flows of companies is significant and direct.

\section{Table 4}

Effect of leverage and control variables on future cash flows

\begin{tabular}{lcccc}
\hline Variables & Coefficient & Standard error & $\mathrm{t}$ & P-value \\
\hline C & 0.140987 & 0.056337 & 2.502543 & 0.0127 \\
LEV & -0.292288 & 0.074554 & -3.920477 & 0.0001 \\
LEV(-1) & 0.278381 & 0.086363 & 3.223389 & 0.0014 \\
LEV(-2) & -0.108714 & 0.065319 & -1.664357 & 0.0967 \\
INV & -0.791503 & 0.094829 & -8.346592 & 0.0000 \\
DIV & 0.764715 & 0.087746 & 8.715130 & 0.0000 \\
TAX & 0.083426 & 0.434472 & 0.192017 & 0.8478 \\
TGAST & 0.113873 & 0.050106 & 2.272665 & 0.0235 \\
SIZE & -0.003317 & 0.003904 & -0.849537 & 0.3960 \\
GROWTH & 0.014204 & 0.004919 & 2.887900 & 0.0040 \\
\hline R ${ }^{2}$ & 0.527 & & $\mathrm{~F}$ & 61.203 \\
D.W. & 1.925 & & P-value & 0.0000 \\
\hline
\end{tabular}

Model 2 has studied the explanatory power of cash flow in future cash flow prediction. The results of regression are shown in Table 5.

Table 5

Effect of cash flows and control variables on future cash flows

\begin{tabular}{llccc}
\hline Variable & Coefficient & Standard error & $\mathrm{t}$ & P-value \\
\hline C & 0.115142 & 0.051619 & 2.230617 & 0.0262 \\
FCFF(-1) & 0.082221 & 0.053591 & 1.534223 & 0.1256 \\
FCFF(-2) & 0.100909 & 0.045790 & 2.203753 & 0.0280 \\
INV & -0.856388 & 0.097296 & -8.801899 & 0.0000 \\
DIV & 0.731116 & 0.077003 & 9.494597 & 0.0000 \\
TAX & -0.027749 & 0.428453 & -0.064766 & 0.9484 \\
TGAST & 0.113099 & 0.043969 & 2.572266 & 0.0104 \\
SIZE & -0.004270 & 0.003513 & -1.215373 & 0.2248 \\
GROWTH & 0.010793 & 0.004662 & 2.315041 & 0.0210 \\
\hline R2 & 0.534 & & $\mathrm{~F}$ & 71.038 \\
D.W. & 2.155 & & P-value & 0.0000 \\
\hline
\end{tabular}


The interpretation of regression analysis using table 5 is as follows:

According to Fischer's results in model 2, the statistic $\mathrm{F}$ is larger than critical figure and their significance area is less than 0.05 . Therefore, there is a linear relationship between independent and dependent variables. In addition, Durbin Watson statistic in model 2 is between 1.70 and 2.30 suggesting lack of autocorrelation in fitted model. $\mathrm{R}^{2}$ coefficient shows that about $53 \%$ of cash flow changes are determined by 8 explanatory variables. Statistic $t$ for Tax shield, size, previous period free cash flow was smaller than critical figure and calculated significance area was higher than 0.05 suggesting the no significant impact of these three variables.

Other explanatory variables of the model were found significant. Therefore one can assume that impact of 2 previous times period free cash flow, dividend, ratio of fixed assets and growth opportunities over cash flows of companies is significant and inverse. Model 3 has studied the explanatory power of leverage and cash flow in future cash flow prediction. The results of regression are shown in Table 6.

\section{Table 6}

Effect of leverage, cash flows and control variables on cash flows

\begin{tabular}{lcccc}
\hline Variable & Coefficient & Standard error & $\mathrm{T}$ & P-value \\
\hline C & 1.238454 & 0.341544 & 3.626049 & 0.0003 \\
LEV & -0.600879 & 0.077927 & -7.710748 & 0.0000 \\
LEV(-1) & 0.080900 & 0.071141 & 1.137180 & 0.2562 \\
LEV(-2) & -0.190270 & 0.057040 & -3.335732 & 0.0009 \\
FCFF(-1) & -0.188634 & 0.043569 & -4.329553 & 0.0000 \\
FCFF(-2) & -0.154017 & 0.038317 & -4.019491 & 0.0001 \\
INV & -0.685007 & 0.087833 & -7.798934 & 0.0000 \\
DIV & -0.203183 & 0.118249 & -1.718269 & 0.0866 \\
TAX & -1.326856 & 0.847294 & -1.565994 & 0.1182 \\
TGAST & -0.128574 & 0.095553 & -1.345577 & 0.1793 \\
SIZE & -0.057432 & 0.024799 & -2.315883 & 0.0211 \\
GROWTH & 0.002873 & 0.006995 & 0.410657 & 0.6816 \\
\hline R2 & 0.741 & & $\mathrm{~F}$ & 7.728 \\
D.W. & 1.947 & & P-value & 0.0000 \\
\hline
\end{tabular}

The interpretation of regression analysis using Table 7 is as follows:

According to Fischer's results in model 3, the statistic $\mathrm{F}$ is larger than critical figure and their significance area is less than 0.05 . Therefore, there is a linear relation between independent and dependent variables. In addition, Durbin Watson statistic in model 3 is between 1.70 and 2.30 suggesting lack of autocorrelation in fitted model. $\mathrm{R}^{2}$ coefficient shows that about $74 \%$ of future cash flow changes is determined by 11 explanatory variables. Statistic $t$ for Tax shield, size, previous period leverage, dividend and ratio of fixed assets were smaller than critical figure of 1.96 and calculated significance area was higher than 0.05 suggesting the non significant impact of these five variables. Other explanatory variables of the model were found significant. Therefore, one can assume that impact of leverage, two times previous period leverage, previous period free cash flow, two time previous period free cash flow, investment level and size over future cash flows of companies is significant and inversed.

\section{Conclusion}

In the present study, the effect of current period financial leverage, financial leverage with time lag, free cash flow of firm with time lag, a set of control variables such as investment level, dividend, tax shield advantages, ratio of fixed assets to total assets, firm size, growth opportunities, profitability in 
future free cash flow forecast in Tehran stock exchange listed companies were investigated. The study was performed in terms of relation between cash flow with leverage level based on signaling Theory and Pecking order Theory. The results showed that financial leverage, cash flow, combination of financial leverage and cash flow together with a set of control variables could be used for forecasting of future cash flows in Tehran stock exchange listed companies. Additionally, combinational model of leverage and cash flow had better forecasting potential comparing with two other models, which means that combinational use of financial leverage and free cash flow with time lag improves the model. Therefore, it would be better for investors to use both of these variables in future cash flow forecasts.

The study results revealed that a negative relation exists between leverage level and cash flow at present time means that any increase in current financial leverage reduce their free cash flows of Tehran stock exchange listed companies and vice versa which is complied with Pecking order Theory. There is a opposite condition for financial leverage with time lag, which means that in a intertemporer level, a positive relation exists between current leverage and future cash flows which is complied with signaling theory. Therefore, the present study result, like previous studies, emphasize that signaling Theory and Pecking order Theory are significant concepts in capital structure theories to explain the relation between leverage (level of using debt) and cash flows of the companies.

\section{Acknowledgment}

The authors would like to thank the officials for Tehran Stock Exchange for supporting this paper by providing the necessary information. We are also grateful for the support of Islamic Azad University.

\section{References}

Blazenko, G. (1987). Managerial preference, asymmetric information, and financial structure. Journal of Finance, 42, 839-862.

Chen, J \& Roger, S. (2005). The determinants of capital structure: Evidence from Chinese listed companies. Economic Change and Restructuring, 38(1), 11-35.

Harris, M \& Raviv, A. (1991). The theory of capital structure. Journal of Finance, 46, 297-356.

Jalali, F. (2003). To study the relationship between capital structure (financial leverage) and cash flow for food industry group in Tehran Stock Exchange. Master degree thesis in accounting, Faculty of social and economical science, Alzahra University.

Mehrani, S., \& Rasaeian, A. (2007). Study on profitability rates and capital structure in Tehran Stock Exchange. Accounting Studies Journal, Alameh Tabatabaei University, 18, 59-80.

Myers, S., \& Majluf, N. (1984). Corporate financing and investment decisions when firms have information that investors do not have. National Bureau of Economic Research, Working Paper 1396.

Poitevin, M. (1989). Financial signalling and the deep pocket. Journal of Economics, 20, 26-40.

Ravid, S., \& Sarig, O. (1991). Financial signalling by committing to cash outflows. Journal of Financial and Quantitative Analysis, 26, 165-180.

Ross, S. (1977). The determination of financial structure: The incentive-signalling approach. Journal of Economics, 8, 23-40.

Ross, S.A., Westerfield, R.W. \& Jaffe, J.F. (2002). Corporate Finance, NewYork.

Rezvani Raz, K., \& Haghighat, H. (2005). To survey the relationship between free cash flows and debt rate with considering the investment opportunities and size in Tehran Stock Exchange listed companies. Management Scholarly Scientific Journal, $2^{\text {nd }}$ year, 5, 50-57.

Rahimian, N. (2001). Review of funding methods in economical units. Accountant magazine.

Salavati, Sh., \& Rasaeian, A. (2007). To study the relationship between capital structure and liquidity of stock. Mofid Economical Letter, 63, 143-163. 
Shenoy, C., \& Koch, P.D. (1995). The firm's leverage-cash flow relationship. Journal of Finance, 2, 307-331.

Wahyudi, I. (2011). Analysis the effect of leverage and cash flow today on future financial performance of Indonesian public company: signaling theory vs. the pecking order theory. 